\title{
Highlights of the edition
}

Welcome to the October 2017 edition of the Journal of the Royal Army Medical Corps. I've led the issue with my Editor's choice paper from our Canadian colleagues discussing the future potential applications of resuscitative endovascular balloon occlusion of the aorta. ${ }^{1}$ Noncompressible thoracic haemorrhage remains the second most common cause of death on the battlefield and currently the only methods for effectively managing it in the prehospital setting are through thoracotomy and of course prevention using personal armour. ${ }^{2}$

Colonel David Woods' group ask the difficult questions as to whether military training results in reproductive dysfunction in a manner analogous to civilian athletes and have identified lines of future potential research. ${ }^{3}$ As many of you are aware Major Daniel Stinner is a US military surgeon currently undertaking research at Imperial College London and has recently joined our international editorial board. His group have published in this edition about the effectiveness of foot fasciotomies in foot

Correspondence to Johno Breeze, Academic Department of Military Surgery and Trauma, Royal Centre for Defence Medicine, Institute of Research and Development, Birmingham Research Park Research Park, Birmingham B15 2SQ, UK; editor.jramc@bmj.com and ankle trauma which I would encourage you to read and I hope reflects even more submissions in the future from our US colleagues. ${ }^{4}$

A review by our French military colleagues into blast ear has demonstrated that the significant functional signs caused by such events, but more interestingly that such signs are not correlated to otoscopic examinations. ${ }^{5}$ Blast Injury has been a significant source of morbidity for UK service personnel and significant research in terms of active ear prevention is still required before an acceptable form of personal protective equipment is found. ${ }^{6}$ I would also recommend the reading of another paper by our US colleagues regarding the implications of critical care management in terms of traumatic brain injury and in flight intra-cranial pressure monitoring. ${ }^{7}$

The editorial board are currently in the process of finalising a special edition on blast Injury which is pencilled in for the February edition and as well as an edition for Immediate responses to terrorist threats which is planned for April 2018. Although both editions are well away any authors wishing to contribute should contact me by the email below.

Provenance and peer review Not commissioned; internally peer reviewed. (c) Article author(s) (or their employer(s) unless otherwise stated in the text of the article) 2017. All rights reserved. No commercial use is permitted unless otherwise expressly granted.

To cite Breeze J. J R Army Med Corps 2017;163:295.

Received 26 September 2017 Accepted 26 September 2017

J R Army Med Corps 2017;163:295

doi:10.1136/jramc-2017-000864

\section{REFERENCES}

1 Smith SA, Hilsden R, Beckett A, et al. The future of resuscitative endovascular balloon occlusion in combat operations. J R Army Med Corps 2017;163:296-300.

2 Breeze J, Lewis EA, Fryer $R$, et al. Defining the essential anatomical coverage provided by military body armour against high energy projectiles. J R Army Med Corps 2016;162:284-90.

3 Gifford RM, Reynolds RM, Greeves J, et al. Reproductive dysfunction and associated pathology in women undergoing military training. J R Army Med Corps 2017;163:301-10.

4 Bedigrew KM, Stinner DJ, Kragh JF, et al. Effectiveness of foot fasciotomies in foot and ankle trauma. J R Army Med Corps 2017;163:324-8.

5 Ballivet de Régloix S, Crambert A, Maurin 0, et al. Blast injury of the ear by massive explosion: a review of 41 cases. J R Army Med Corps 2017;163:333-8.

6 Patil ML, Breeze J. Use of hearing protection on military operations. J R Army Med Corps 2011;157:381-4.

7 Boyd LR, Borawski J, Lairet J, et al. Critical care air transport team severe traumatic brain injury short-term outcomes during flight for operation Iraqi freedom/ operation enduring freedom. J R Army Med Corps 2017:163:342-6. 